\title{
Oil-Gas and Environmental Nexus: Impact of Human Actions on selected Soil Physicochemical Parameters in Port Harcourt and its environment, Nigeria
}

\author{
${ }^{1}$ MUYOMA, WP; ${ }^{2}$ ODOKUMA, L; ${ }^{3}$ IBISIME, E; ${ }^{4}$ RAMKAT, R
}

\author{
${ }^{I}$ Department of Biological Sciences, Moi University, P. O. Box 7648 30100, Eldoret, Kenya \\ ${ }^{2}$ Department of Microbiology, University of Port Harcourt, Nigeria \\ ${ }^{3}$ Department of Animal Science, University of Port Harcourt, Nigeria \\ 4 Center of Excellence in Phytochemicals, Textiles and Renewable Energy, Moi University, Eldoret, Kenya \\ *Corresponding Author Email: piwanjala@gmail.com, \\ ibisime.etela@uniport.edu.ng; chirirose@yahoo.com
}

\begin{abstract}
Impact of oil and gas activities on quality of soil in Port Harcourt and its environments was assessed. The study evaluates levels of physicochemical parameters associated with oil and gas industry in soils of 9 locations in Port Harcourt and its environs in Rivers State in Nigeria using standard methods. Composite samples were collected by random sampling from each of the 9 test locations, 3 control samples were also collected from each of the study areas. Benzene, Toluene, Ethyl-benzene, and Xylene (BTEX) and Total Petroleum Hydrocarbon (TPH) was measured using Gas Chromatography (Hewlett Packard 5890 Series II Gas Chromatograph FID). Total Organic Carbon (TOC) was measured using ASMD standard methods of analysis (ASMD 2579). Refinery Eleme and Aluu recorded the highest mean levels of BTEX (3.21 \pm 0.61 and $3.24 \pm 0.18$ ppm respectively). The mean levels of TPH in soil were within the EPA acceptable optimum of $50 \mathrm{mg} / \mathrm{kg}$ except at A2 (Oquwi). There was significant difference among test samples and control samples as determined by one-way ANOVA (F11, 24=3.395; $\mathrm{p}=0.006)$. The highest mean levels of TPH was at A2 $(56.70 \pm 25.77$ $\mathrm{ppm})$. ANOVA revealed that there were significant differences in TOC $(\mathrm{p}=0.023), \operatorname{BTEX}(\mathrm{p}=<0.001)$ and TPH $(\mathrm{p}=<0.001)$ among the study areas. Industrial areas I1 [Onne], I2 [Agbada] and I3 [Trans-Amadi] recorded highest levels of TOC. Oil and gas activities in industrial areas in Port Harcourt have highest impact on levels of TOC in soils as compared to agricultural and urbanized areas. Oil and gas activities have negative impact on levels of BTEX. Industrial areas recorded highest levels followed by agricultural areas and lastly urbanized areas. The study concludes that oil and gas activities are a threat to soil health and integrity in Port Harcourt.
\end{abstract}

\section{DOI: https://dx.doi.org/10.4314/jasem.v22i11.23}

Copyright: Copyright $\odot 2018$ Muyoma et al. This is an open access article distributed under the Creative Commons Attribution License (CCL), which permits unrestricted use, distribution, and reproduction in any medium, provided the original work is properly cited.

Dates: Received: 17 November 2018; Revised: 26 November 2018; Accepted 30 November 2018

Keywords: oil, gas, environment, soil, pollution, physicochemical parameters, nexus

Oil/gas industry also known as petroleum industry and includes processes of exploration, extraction, refining, transportation and marketing of petroleum products. During exploration, seismic surveys produce voluminous sounds that affect commercial species in water bodies and spawning grounds for the fishes. Extraction mud and cuttings are deposited on drilling sites which cause organic enrichment and accumulation of toxins. Further, production water contains naturally occurring heavy metals, radionucleotides and oilfield chemicals. Refining of oil releases toxins to the atmosphere and effluent that contaminate soils and water bodies. Transportation and marketing are key processes in the oil and gas industry. During transportation, oil spills may occur along the pipelines, at the flow stations, cars, airplane, boats and trucks. History recalls some of the major oil spills; 1989 Exx Valdez in Alaska and 2010 BP deep water Horizon in Mexico, but hardly is the cumulative small spills from cars, boats, pipelines and airplanes accounted for. Oil is a raw material for many chemical products including pharmaceuticals, solvents, fertilizers, pesticides, synthetic fragments and plastics. Oils spills are common scenario and negatively linked to pollution of the environment and its inhabitants. Contaminants from oil to the environment include; paraffins, alkanes, cycloalkanes, aromatics (BTEX and TPHs), alkynes, alkenes, Sulphur, Nitrogen and heavy metals. Oil spills affect human health directly by penetrating through into the body, in foodstuffs and inhalation of fumes, or indirectly through destruction of recreational and agricultural activities. Oil spills in land penetrate vertically to contaminate underground water. Natural barriers like clay can restrict vertical movement and thus soil type is necessary to forecast possible contamination of underground water in case of a spill.

Nigeria is one of the largest crude oil producing nations in Africa and globally (Gboyega et al., 2011). 
Rivers State is one of the centers of Nigerian Oil Industry with a high number of companies including; Shell Petroleum Development Company of Nigeria, AGIP, Texaco, Elf, NPRC, Michelin, West African Glass Industry, Alcan Aluminium, Metaloplastica, Risonpalm, NAFCON, Padbod Breweries among others (Chete et al., 2011). These are possible sources of organic and inorganic wastes that may pollute the environment. Organic wastes are simply biodegradable materials that are produced as agricultural wastes, market wastes, urban solid food wastes and municipal solid wastes (Chete et al., 2011). Organic wastes are among the leading sources of organic pollutants to water bodies, air, and soil. Inorganic wastes include non-biodegradable materials including; plastics, glass, metals, textiles, rubber, ewastes, ash and other inert materials (World Bank, 2012).

Soil particle size plays a critical role as it influences the capacity of soil to hold water and nutrients (MIRA, 2012) and also can influence capacity of pollutants to penetrate vertically or horizontally to contaminate underground waters. Naturally, nitrogen exists in soil typically bound to organic matter or mineral soil material as either nitrate or nitrite, which are salts that can completely dissolve in water. Nitrates and nitrites can naturally be found in igneous and volcanic rocks. Animal wastes and nitrogen-containing fertilizers can increase concentration of nitrate in the soil. Bacteria can convert nitrite to nitrate hence affecting its availability and distribution in the environment. Human consumption of huge concentrations of nitrates can lead to decreased capacity of blood to transport oxygen (methemoglobinemia), low blood pressure, tachycardia, headaches, abdominal cramps and occasionally is fetal. The maximum contaminant level for nitrate is $1 \mathrm{mg} / \mathrm{L}$ and for nitrite is $3.3 \mathrm{mg} / \mathrm{L}$ (United States Environmental Protection Agency [U.S. EPA]). Phosphates occur naturally in soils and found in elemental form and free phosphate ion in solution also called inorganic phosphate. Benzene, toluene, ethylbenzene and xylene (BTEX) are highly volatile, with high mobility and are detectable in oil contaminated environments and are considered toxic and carcinogenic (Pinedo et al., 2013). Benzene is the most hazardous due to its carcinogenic and toxic characteristics (Ma, Martínez-pagán et al., 2014), where recommended limit is a maximum level of 5 $\mu \mathrm{g} / \mathrm{kg}$ (U.S. EPA). Electrical conductivity is a measure of salts in soil and is an important soil health indicator.
Electrical conductivity affects nutrient accessibility, and Microbial activities in the soil which influence key soil processes (Smita \& Ingole, 2015). Soil pH is important as it affects all other parameters (Mccauley et al., 2017). A pH of less than 6 is acidic while a $\mathrm{pH}$ above 8.5 is alkaline soil (Mccauley et al., 2017). Potassium does not form major component of plant but is involved in many plant metabolic processes ranging from formation of cellular components to regulation of photosynthesis (Smita \& Ingole, 2015). Potassium is found in mineral form and affects cell division in plants, carbohydrate formation, translocation of sugars, enzyme action and disease resistance (Prajapati $\&$ Modi, 2012). Total organic carbon (TOC) is carbon stored in soil organic matter and is derived through decomposition of living and dead organisms. In soils, Sulphur exists in organic and inorganic form and is cycled between the two forms by means of mobilization, immobilization, oxidation and reduction and mineralization. Sulphur is essential building block for proteins in plants and it can only be taken up from the soil solution as sulphate (Edwards, 1998). Of the 17 essential elements for plant growth, Sulphur (S) is considered the fourth important after Nitrogen $(\mathrm{N})$, Phosphorous (P) and Potassium (K) in terms of plant requirement (Hopkins, 1999). Sulfur is found in commercial fungicides; Cosan, Crisazufre, Hexasul, Sulflox, Tiolene, and Thiolux, among others. Sulphur is known of low or little toxicity to human and animal health but can affect populations of microorganisms in soil. It is available in soil to plant and microbes mostly as sulphate. Sulphate in soils comes through soil minerals, fertilizers and pesticides and may be lost through reduction from inorganic Sulphur to sulphate by microorganisms; heterotrophic bacteria and fungi (Amponsah \& Nagai, 2014). Sulphate can also be lost through reduction to Hydrogen Sulphide and through anaerobic respiration (Amponsah et al., 2014). Total petroleum hydrocarbons (TPH) refers to a large family of several hundred chemical compounds; hexane, jet fuels, mineral oils, benzene, toluene, xylenes, naphthalene, and fluorene, that originally come from crude oil and are all made from hydrogen and carbon (Todd et al., 1999). Total Petroleum Hydrocarbon (TPH) released to the soil may move through the soil and dissolve to the groundwater and move away to different areas from the release areas whereas some will evaporate into air. Some compounds will be attached to soil particles and be broken down by organisms (Todd et al.,1999). 


\section{MATERIALS AND METHODS}

Description of the Study Site: This study was conducted in 9 selected areas of Port Harcourt, the Capital of Rivers State, Nigeria (Figure 1). The areas of interest were grouped into 3; urban, industrial and agricultural areas. The urban areas of interest included; GRA phase 2, Diobu- Mile 1 and Mguoba. Agricultural areas of interest included; Aluu, Oquwi- Eleme, Emuoha- Eu, while the industrialized areas were; Eleme which hosts the NNPC Refinery, Agbada-SPDC- flow station in a rural setting and Trans-Amadi. The characteristics and main activities (Table 1) conducted in the study areas include; drilling and mining, fishing, fish farming, horticulture, dairy farming and crop farming, industrial processing. The study areas were assigned codes as in Table 1.

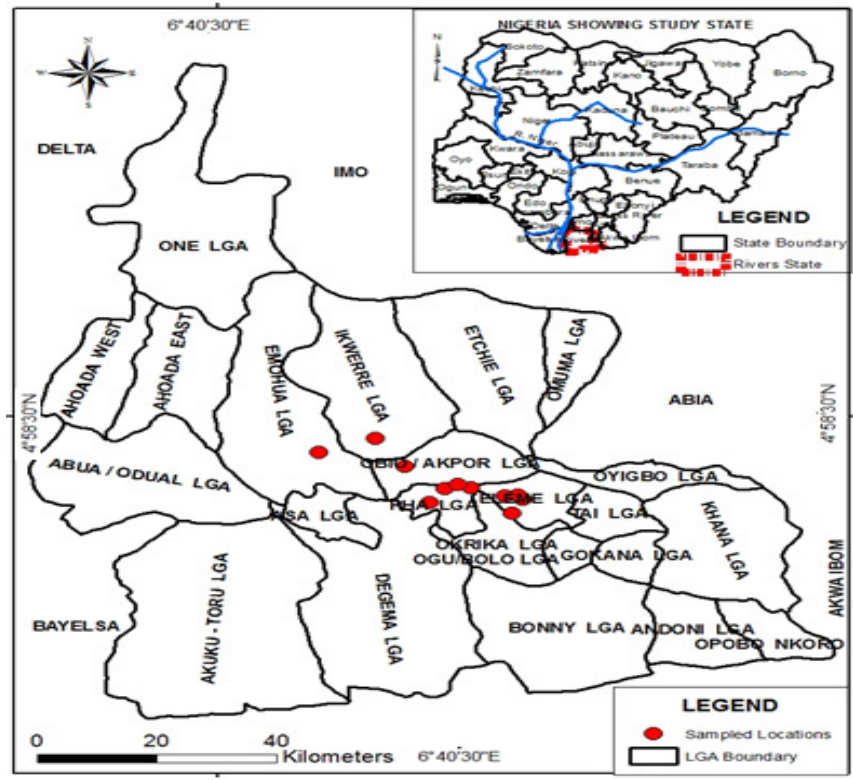

Fig 1: Map of Nigeria showing sampled locations in Rivers State

Table 1: Table showing study areas and economic activities

\begin{tabular}{|c|c|c|c|c|}
\hline No & $\begin{array}{l}\text { S elected } \\
\text { study } \\
\text { areas }\end{array}$ & $\begin{array}{l}\text { Study } \\
\text { area } \\
\text { coding }\end{array}$ & $\begin{array}{l}\text { Coordinates/ } \\
\text { N Latitude } \\
\text { E Longitude }\end{array}$ & Economic activities \\
\hline \multicolumn{5}{|c|}{ Agricultural areas } \\
\hline $\mathbf{1}$ & Alus & A.1 & $\begin{array}{l}4=56,11.160 ; \\
6=57,52.248\end{array}$ & Flow station \\
\hline 2 & $\begin{array}{l}\text { Oquwi- } \\
\text { Eleme }\end{array}$ & A.2 & $\begin{array}{l}4^{\circ} 44^{\prime}, 09.874^{\prime}, \\
7^{\circ}=8,58.494^{\prime}\end{array}$ & $\begin{array}{l}\text { Village close } \\
\text { refinery }\end{array}$ \\
\hline 3 & Emvoha & A. 3 & $\begin{array}{l}5^{\circ} 00=00.018^{\prime}, \\
6^{\circ} 49=13.032^{\prime},\end{array}$ & Flow station \\
\hline 4 & Control & CA & $\begin{array}{l}5=00,21.384 \\
6=49=00.000\end{array}$ & $\begin{array}{l}>1 \mathrm{~km} \text { away from } \\
\text { suspected areas }\end{array}$ \\
\hline \multicolumn{5}{|c|}{ Ind ustrial areas } \\
\hline 1 & $\begin{array}{l}\text { Onne- } \\
\text { Eleme }\end{array}$ & n & $\begin{array}{l}4^{\circ} 46^{\prime}, 00.402^{\prime} \\
7^{\circ} 05,43.092^{\prime}\end{array}$ & $\begin{array}{l}\text { Hosts the NMPC } \\
\text { Refinery }\end{array}$ \\
\hline 2 & Agbada & I2 & $\begin{array}{l}4^{\circ}=56^{\prime} 03.444^{\prime}, \\
6^{\circ} 58^{\prime} 42.060^{\prime}\end{array}$ & $\begin{array}{l}\text { Hosts S PDC- flow } \\
\text { station in a rural setting }\end{array}$ \\
\hline 3 & $\begin{array}{l}\text { Trans- } \\
\text { Amadi }\end{array}$ & I3 & $\begin{array}{l}4=48,20.455, \\
7=02,17.646\end{array}$ & $\begin{array}{l}\text { Schlumberger', } \\
\text { Hallburton. }\end{array}$ \\
\hline 4 & Control & CI & $\begin{array}{l}4^{\circ} 47^{\prime}=13.788^{\prime} \\
7^{\circ} 07^{\prime}=44.620^{\prime}\end{array}$ & $\begin{array}{l}>1 \mathrm{~km} \text { away from } \\
\text { suspected areas }\end{array}$ \\
\hline \multicolumn{5}{|c|}{ Urban areas } \\
\hline 1 & $\begin{array}{l}\text { GRA } \\
\text { phase 2 } \\
\text { Diobu- } \\
\text { Mile 1 }\end{array}$ & $\begin{array}{l}\mathrm{U} 1 \\
\mathrm{U} 2\end{array}$ & $\begin{array}{l}4^{\circ} 49^{\prime} 53.574^{\prime} \\
6^{\circ} 59^{\prime} 45.552^{\prime} \\
4^{\circ} 47^{\prime}=20.382^{\prime} \\
7^{\circ}, 00^{\prime} 13.164^{\prime}\end{array}$ & $\begin{array}{l}\text { Inhabited areas } \\
\text { Perecuma street } \\
\text { Petroleum refinery }\end{array}$ \\
\hline 3 & $M_{\text {guoba }}$ & U3 & $\begin{array}{l}4^{\circ} 50,39.864, \\
6=58,20.232,\end{array}$ & NTA \\
\hline 4 & Control & $\mathrm{CU}$ & $\begin{array}{l}4^{\circ} 49^{\prime}, 17,040^{\prime} \\
6^{\circ} 59^{\prime}, 24.168^{\prime}\end{array}$ & $\begin{array}{l}>1 \mathrm{~km} \text { away } \\
\text { suspected areas }\end{array}$ \\
\hline
\end{tabular}

Sampling: Composite samples were collected by random sampling from each of the three areas; urbanized, industrialized and agricultural in the wet season (April to October 2018). Five (5) individual samples were collected following a random pattern around each test field. The five individual samples were thoroughly mixed by coning and quartering in a sterile container to attain a homogenous composite mixture. A total of 12 composite samples; A1, A2, A3, I1, I2, I3 U1, $\mathrm{U} 2$ and $\mathrm{U} 3$ as test samples, and CA, $\mathrm{CI}$ and $\mathrm{CU}$ as control samples (Table 1), were collected from the topsoil within a depth of 0 to $15 \mathrm{~cm}$ using a standard auger 3 times in the rainy season. Homogenized composite samples (400 gm) were then packed in polyethylene bags using a sterile wooden shovel. Samples for microbial analysis were collected using pre-sterilized materials to prevent contamination of the samples. Locations of the sampling sites were identified using a GPS and the GPS readings recorded. Samples were transported to the laboratory for analysis.

\section{RESULTS AND DISCUSSION}

Physicochemical Parameters: Soil $p H$ : The soil $\mathrm{pH}$ of samples from in the 9 study areas varied from 4.5 to 10.30 (Table 2) over the study period, where some values were below or above the required EPA 816-F-09-004 limits of 6.5-8.5 (Table 2). The $\mathrm{pH}$ showed a decreasing trend from April to September (Figure 2).

Other Physicochemical Parameters:

Particle size

There was no significant difference in particle size in soils among test samples and controls as determined $(\mathrm{p}=1.000) \quad$ [Figure 3]. Refinery Eleme (I1) recorded the highest mean level of particle size (45.13 \pm 27.43$)$.

Electrical conductivity

Electrical conductivity recorded mean values within the WHO 
acceptable optimum of $20 \mu \mathrm{S} / \mathrm{m}$. There was no significant difference among test samples and control samples as determined $(\mathrm{p}=0.098)$. GRA phase 2 (U1) had the highest fluctuation with a minimum of $0.13 \mu \mathrm{S} / \mathrm{m}$ in April and a maximum of $0.57 \mu \mathrm{S} / \mathrm{m}$ in September. The highest mean value of electrical conductivity (EC) was recorded at $\mathrm{A} 2 ; 0.29 \pm 0.24$ $\mu \mathrm{S} / \mathrm{m}$ (Table 3).

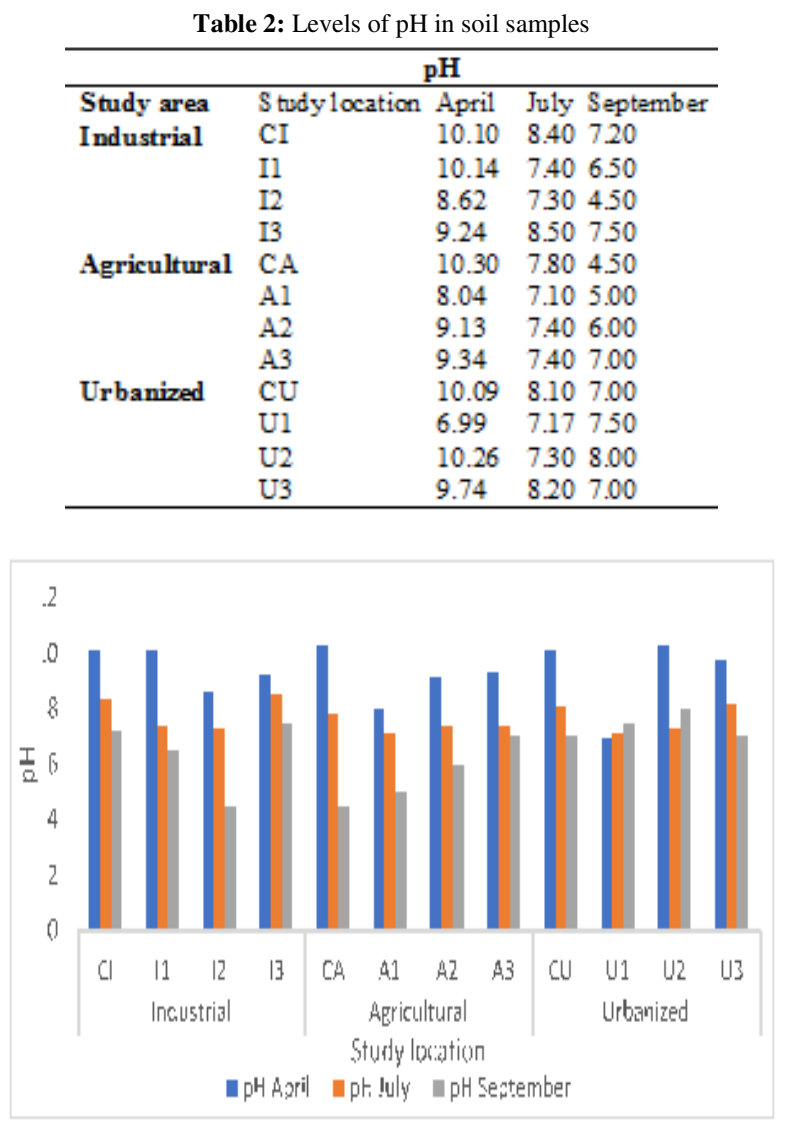

Fig 2: Variation in $\mathrm{pH}$ over the study areas in the wet season

Nitrate: The mean levels of nitrate in soil were above the EPA 816-F09-004 acceptable optimum value of 100 to $500 \mathrm{mg} / 100 \mathrm{~g}$ (Table 3). There was no significant difference among test samples and control samples $(\mathrm{p}=0.172)$. Ogali $(\mathrm{CI}) 848.99 \pm 95.96 \mathrm{mg} / 100 \mathrm{~g}$ and GRA U1 (738.84 \pm 63.43$)$ recorded the highest levels of nitrates.

Nitrite: The mean levels of nitrites $\left(\mathrm{NO}_{2}{ }^{-}\right)$in soil samples were above the EPA 816-F-09-004 acceptable optimum range of $40 \mathrm{mg} / 100 \mathrm{~g}$. There was no significant difference among test samples and control samples $(\mathrm{p}=0.170)$. The highest values of $\mathrm{NO}_{2}^{-}$were recorded in $\mathrm{CI}$; $630.61 \pm 122.85 \mathrm{U} 1 ; 558.48 \pm 82.46$ and U3; $433.52 \pm 362.01$ (Table 3).

Phosphate: The mean levels of phosphate in soil were within the WHO acceptable optimum of $20,000 \mathrm{mg} / 100 \mathrm{~g}$. There was no significant difference among test samples and control samples $(\mathrm{p}=0.170)$. Eleme [I1]

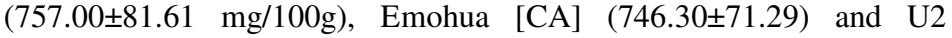
$(920.93 \pm 124.53 \mathrm{mg} / 100 \mathrm{~g})$ recorded the highest levels of phosphate.
Sulphates: The mean levels of sulphates in soil were within the WHO acceptable optimum range of from 200 to $300 \mathrm{mg} / 100 \mathrm{~g}$. There was no significant difference among test samples and control samples $(\mathrm{p}=0.431)$ [Figure 3]. Oquwi (A2) area recorded the highest levels of sulphate $(139.34 \pm 110.89 \mathrm{mg} / 100 \mathrm{~g})$.

Sulphur: The mean levels of Sulphur in soil were within the WHO acceptable optimum of 500 $\mathrm{mg} / \mathrm{g}$. There was no significant difference among test samples and control samples $(p=0.175)$. Oquwi (A2) area recorded the highest levels of Sulphur $(51.94 \pm 35.06 \mathrm{mg} / \mathrm{kg})$.

TPH: The mean levels of TPH in soil were within the EPA acceptable optimum of $50 \mathrm{mg} / \mathrm{kg}$. There was significant difference among test samples and control samples $(\mathrm{p}=0.006)$. The highest mean levels of TPH was at A2 (56.70 \pm 25.77 ppm) [Table 4].

BTEX: The mean levels of BTEX in soil in some areas was above the US acceptable maximum value 0.05 $\mathrm{mg} / \mathrm{kg}$ (ppm) [US EPA 5021]. There was significant difference among test samples and control samples $(\mathrm{p}=0.004)$. Eleme (I1) and A1 recorded the highest levels of BTEX (3.21 \pm 0.61 and $3.24 \pm 0.18 \mathrm{ppm}$ respectively).

TOC: The mean levels of $\%$ TOC in soil were above the U.S. EPA priority compounds acceptable optimum range of TOC $3 \%$ by weight. There was significant difference among test samples and control samples $(\mathrm{p}=0.023)$ [Figure $3]$. Eleme (I1), I2 and I3 recorded the highest levels of \% TOC, $8.32 \pm 0.86,8.31 \pm 2.33$ and $9.54 \pm 1.94$ respectively (Table 4$)$. 
Table 3: Mean concentration $( \pm \mathrm{SD})$ of physicochemical parameters in soil samples

\begin{tabular}{llllll}
\hline $\begin{array}{l}\text { Study } \\
\text { Location }\end{array}$ & $\begin{array}{l}\text { Particle } \\
\text { Size }(\% \mathbf{W t})\end{array}$ & $\begin{array}{l}\text { Electrical } \\
\text { Conductivity } \\
(\boldsymbol{\mu} / \mathbf{c m})\end{array}$ & Nitrate $(\mathbf{m g} / \mathbf{1 0 0 g})$ & Nitrite $(\mathbf{m g} / \mathbf{1 0 0 g})$ & Phosphate $(\mathbf{m g} / \mathbf{1 0 0 g})$ \\
\hline CI & $37.91 \pm 51.85$ & $0.12 \pm 0.07$ & $848.99 \pm 166.20$ & $630.61 \pm 122.85$ & $668.10 \pm 14.55$ \\
I1 & $45.13 \pm 47.50$ & $0.09 \pm 0.05$ & $28.37 \pm 37.99$ & $21.42 \pm 27.98$ & $757.00 \pm 141.35$ \\
I2 & $32.37 \pm 40.38$ & $0.04 \pm 0.00$ & $504.84 \pm 343.03$ & $352.51 \pm 260.20$ & $657.27 \pm 17.27$ \\
I3 & $33.02 \pm 42.65$ & $0.09 \pm 0.03$ & $462.39 \pm 463.83$ & $321.33 \pm 359.14$ & $664.99 \pm 17.45$ \\
CA & $40.48 \pm 58.20$ & $0.05 \pm 0.02$ & $390.49 \pm 358.31$ & $373.04 \pm 269.89$ & $746.30 \pm 123.47$ \\
A1 & $27.60 \pm 34.71$ & $0.13 \pm 0.07$ & $105.99 \pm 89.96$ & $78.59 \pm 66.75$ & $667.63 \pm 12.26$ \\
A2 & $39.23 \pm 56.28$ & $0.29 \pm 0.24$ & $444.68 \pm 338.07$ & $353.63 \pm 238.07$ & $654.26 \pm 24.41$ \\
A3 & $43.08 \pm 57.71$ & $0.09 \pm 0.03$ & $388.96 \pm 368.40$ & $316.55 \pm 261.37$ & $659.72 \pm 32.71$ \\
CU & $32.04 \pm 38.31$ & $0.14 \pm 0.06$ & $451.03 \pm 385.71$ & $348.27 \pm 283.84$ & $518.31 \pm 247.77$ \\
U1 & $35.47 \pm 45.66$ & $0.10 \pm 0.09$ & $738.84 \pm 109.86$ & $558.48 \pm 82.46$ & $663.14 \pm 21.13$ \\
U2 & $46.62 \pm 65.99$ & $0.12 \pm 0.07$ & $265.90 \pm 304.57$ & $220.22 \pm 214.29$ & $920.93 \pm 215.70$ \\
U3 & $41.13 \pm 58.01$ & $0.09 \pm 0.05$ & $577.99 \pm 491.38$ & $433.52 \pm 362.01$ & $658.03 \pm 1.56$ \\
P Value & 1.000 & 0.098 & 0.172 & 0.170 & 0.055 \\
\hline
\end{tabular}

SD: Standard deviation (Significant coefficients $P=0.05$ )

\begin{tabular}{llllll}
\multicolumn{5}{c}{ Table 4: Mean concentration $( \pm$ SD) of physicochemical parameters in soil samples } \\
\hline $\begin{array}{l}\text { Study } \\
\text { Location }\end{array}$ & Sulphate $(\mathbf{m g} / \mathbf{1 0 0 g})$ & Sulphur $(\mathbf{m g} / \mathbf{K g})$ & TPH $(\mathbf{p p m})$ & BTEX $(\mathbf{p p m})$ & \% TOC \\
\hline CI & $26.43 \pm 20.00$ & $11.49 \pm 6.32$ & $5.09 \pm 0.33$ & $1.11 \pm 0.06$ & $7.32 \pm 1.34$ \\
I1 & $71.48 \pm 18.62$ & $24.91 \pm 5.91$ & $7.61 \pm 0.38$ & $3.21 \pm 1.05$ & $8.32 \pm 0.86$ \\
I2 & $8.69 \pm 1.55$ & $2.98 \pm 0.54$ & $8.55 \pm 0.09$ & $1.73 \pm 0.61$ & $8.31 \pm 2.33$ \\
I3 & $41.85 \pm 27.30$ & $13.71 \pm 9.16$ & $13.89 \pm 9.94$ & $1.47 \pm 0.30$ & $9.54 \pm 1.94$ \\
CA & $36.09 \pm 30.82$ & $12.60 \pm 10.29$ & $15.76 \pm 5.77$ & $1.67 \pm 1.05$ & $3.79 \pm 2.59$ \\
A1 & $8.69 \pm 1.61$ & $2.82 \pm 0.59$ & $5.52 \pm 1.12$ & $3.24 \pm 0.31$ & $7.76 \pm 1.94$ \\
A2 & $139.34 \pm 192.06$ & $51.94 \pm 60.72$ & $56.70 \pm 44.63$ & $1.76 \pm 1.16$ & $5.40 \pm 1.39$ \\
A3 & $58.03 \pm 44.57$ & $4.07 \pm 1.02$ & $6.36 \pm 0.06$ & $1.87 \pm 0.89$ & $3.80 \pm 3.29$ \\
CU & $60.68 \pm 64.23$ & $20.65 \pm 21.27$ & $5.16 \pm 1.77$ & $1.77 \pm 0.09$ & $5.06 \pm 1.04$ \\
U1 & $34.75 \pm 1.76$ & $11.89 \pm 0.57$ & $12.60 \pm 5.91$ & $1.62 \pm 0.01$ & $7.62 \pm 3.80$ \\
U2 & $6.15 \pm 0.90$ & $2.13 \pm 0.28$ & $7.20 \pm 2.26$ & $0.81 \pm 0.43$ & $3.17 \pm 3.02$ \\
U3 & $33.09 \pm 18.89$ & $9.85 \pm 6.28$ & $7.72 \pm 0.25$ & $1.51 \pm 0.13$ & $5.22 \pm 1.21$ \\
P Value & 0.431 & 0.175 & 0.006 & 0.004 & 0.023 \\
\hline
\end{tabular}

SD: Standard deviation (Significant coefficients $P=0.05$ )

The pH levels of CI, I1, CA, CU and U2 >9.0 in the month of April that were alkaline and were above the DPR recommended limits of 6.5-9.0 (Table 2/Figure 2). Some $\mathrm{pH}$ levels were below some were above the required DPR limits of 6.5-9.0/ EPA 816-F-09-004 limits of 6.5-8.5. Industrial area (I2) [Agbada] and agricultural control area (CA) [Emohua] recorded a $\mathrm{pH}$ of 4.5 in the month of September. Fluctuation of $\mathrm{pH}$ values can be associated with acid water drainage or from surface runoffs. Runoffs from metal-rich areas usually have acidic $\mathrm{pH}$ and can affect $\mathrm{pH}$ levels in soils. Plants that grow in acidic $\mathrm{pH}$ and alkaline $\mathrm{pH}$ experience a spectrum of challenges including ion in toxification, shortage of nutrient and nutrient imbalances. This is an indication of presence of high levels of either calcium, magnesium or sodium (Mccauley et al., 2017). Organisms that inhabit soils with $\mathrm{pH}$ values that are outside the recommended limits are exposed to low nutrient availability and high levels of toxicity (European Commission, 2013). There was a significant drop in $\mathrm{pH}$ in these areas in the month of September where they were within DPR limits of 6.5-9.0/ EPA 816-F-09-004 limits of 6.5-8.5. This can be attributed to the runoffs that occurred over the period as rain is acidic or neutral. Acid rains can be both beneficial and harmful, as they can neutralize acidic or alkaline soils for benefit of ecosystem integrity. The solubility of $\mathrm{Mn}_{2}{ }^{+}$and $\mathrm{Al}_{3}{ }^{+}$increases in acidic soils leading to toxicity to plants. High $\mathrm{pH}$ values were recorded in the month of April (Table 2) which decreased in the months of July and September (Table 2). Availability of Boron (B), $\mathrm{Cu}, \mathrm{Mn}$, and $\mathrm{Fe}$ depend on $\mathrm{pH}$ levels and tend to decrease with increase in $\mathrm{pH}$, therefore level of $\mathrm{pH}$ of soils remains concern for farmers. Electrical conductivity mean values were within the WHO acceptable optimum of $20 \mu \mathrm{S} / \mathrm{m}$. Elevated levels of EC is an indication of increasing level of salts in the soils. Soils that are affected by $\mathrm{Ca}$, $\mathrm{Mg}, \mathrm{Cl}, \mathrm{SO}_{4}$ or other salts show increased levels of EC. High values of nitrates were recorded in CI; $848.99 \pm 166.20, \quad \mathrm{I} 2 ; \quad 504.84 \pm 343.03$ and $\mathrm{U} 1$; $738.84 \pm 109.86$ (Table 3). Total Nitrogen includes nitrate, nitrite and ammonium. This study focused on the levels of nitrates and level of nitrite. The mean levels of nitrate in soil were within the EPA 816-F-09004 acceptable optimum value of 100 to $500 \mathrm{mg} / 100 \mathrm{~g}$ except for some areas which recorded values above the recommended limits, U1 recorded 848.99 \pm 95.96 
$\mathrm{mg} / 100 \mathrm{~g}$ and $\mathrm{C} 1$ recorded $(738.84 \pm 63.43)$ which were the highest levels of nitrates. Soluble salts from respective solids are easily generated by nitrates, hence nitrates have greatest washout and elution potential. The major sources of nitrates in environment are; industries (oil, pharmaceuticals, sewage, garbage dumpsites, agriculture and food processing industries) which come with emissions to the environment, organic nitrogen found in living organisms and oxides of nitrogen in exhaust fumes. The highest values of $\mathrm{NO}_{2}{ }^{-}$were recorded in $\mathrm{CI} ; 630.61 \pm 122.85 \mathrm{U} 1$; $558.48 \pm 82.46$ and U3; 433.52 \pm 362.01 (Table 3). Readily available form of $\mathrm{P}$ for plants is phosphate $\left(\mathrm{PO}_{4}\right)$. Phosphates occur naturally from elemental phosphorus. In biological systems, Phosphate is found as inorganic phosphate which is a free phosphate ion. The mean levels of phosphate in soil of the study sites were within the WHO acceptable optimum of 20,000 $\mathrm{mg} / 100 \mathrm{~g}$. Availability and fixation of phosphorous vary across $\mathrm{pH}$ ranges. Fluctuation in levels of phosphorous can also be attributed to fixation of phosphates to iron, aluminum and calcium minerals. Eleme (I1) $\quad[757.00 \pm 81.61 \quad \mathrm{mg} / 100 \mathrm{~g}], \quad \mathrm{CA}$ $(746.30 \pm 71.29)$ and $\mathrm{U} 2(920.93 \pm 124.53 \mathrm{mg} / 100 \mathrm{~g})$ recorded the highest levels of phosphate (Table 3 ). Phosphates get into the environment through municipal and industrial wastes, agricultural wastes, plant residues and fertilizers. Phosphates can be removed from the environment through runoffs, sediments and soluble phases. The mean level of Sulphur in soil was were within the WHO acceptable optimum of $500 \mathrm{mg} / \mathrm{g}$. Organic Sulphur is immobile, inorganic Sulphur is mobile and Sulphate is most mobile. Sulphate that is adsorbed by electrostatic charges onto soil limits its mobility. Adsorption and desorption of Sulphate are controlled by $\mathrm{pH}$, sulphate concentrations and other anions and cations in solution. Sources of Sulphur in soil include; fertilizers, pesticides and atmospheric depositions. Inorganic Sulphur is oxidized to sulphate by microorganisms including heterotrophic bacteria and heterotrophic fungi. Sulphate is lost from the soil through anaerobic respiration and reduction to Hydrogen Sulphide. Eleme (I1) area recorded the highest levels of Sulphur $(51.94 \pm 35.06 \mathrm{mg} / \mathrm{kg})$ [Table 4]. The findings are closely related to findings by Abel et al., 2014, who describes Sulphur to exit soil as organic Sulphur compounds, Sulphides (S), elemental Sulphur (S) and Sulphite $\left(\mathrm{SO}_{4}{ }^{2-}\right)$. Variation in Sulphur levels can be associated with uptake by plants, leaching and volatilization (Abel et al., 2014). Total petroleum hydrocarbon (TPH) refers to a broad family of chemical compounds that come from crude oil which vary in chemicals that they contain. The mean levels of TPH in soil were within the EPA acceptable optimum of $50 \mathrm{ppm}(\mathrm{mg} / \mathrm{kg})$. Total petroleum hydrocarbon can be attributed to accidental spills, industrial wastes or as byproducts in processing of crude oil (Kuang et al., 2018). The highest mean levels of TPH was at I1 (Onne) [56.70 $\pm 25.77 \mathrm{ppm}$ ] \{Table $4\}$. The findings are in agreement with the findings of Kuang et al., 2018, which reveal that TPH can be detected in soils which are closest to oil processing sites. The mean levels of BTEX in soil were above the US EPA acceptable maximum value $0.05 \mathrm{mg} / \mathrm{kg}$ [US EPA 5021]. This can be attributed to the varied sources of the contaminant and environmental degradation. BTEX are periodically and variedly found in contaminated soils around many industries, storage tanks, accidental spills and pipeline leakages. Eleme (I1) and Aluu (A1) recorded the highest levels of BTEX (3.21 \pm 0.61 and $3.24 \pm 0.18 \mathrm{ppm})$ respectively [Table 4]. In the study areas, BTEX is influenced by anthropogenic activities. The findings are in agreement with those of Cheng, 2016, where proximity to sources of BTEX can influence contamination levels in the environment, which can be distributed in the environment vertically or horizontally in solvents (Cheng et al., 2016). Total organic carbon (TOC) is derived from putrefying organisms and metabolic activities of living organisms and also from synthetic sources (detergents, fertilizers, chlorinated organics, herbicides and industrial chemicals). Total organic carbon has effects on soil color, nutrient levels (anion and cation exchange), water retention capacity and aeration. Mean level of $\%$ TOC in soil of the study area was $6.28 \pm 0.46$ (Table 4), which was above the USEPA priority compounds acceptable optimum range of TOC is $3 \%$ by weight or $30,000 \mathrm{mg} / \mathrm{kg}$. The apprehension with high levels of TOC in soils is the potential to generate gas and thus should be maintained at low levels. Sustaining low TOC controls the development of biofilms through control of microorganism population. The findings are in agreement with the findings of (Kuang et al., 2018), where TOC were quantified in the study areas. The findings can also be related to findings of Blanchet et al., 2016, where TOC can vary according to activity and soil type (Blanchet et al., 2016), however there was no significant difference in soil types in the study areas.

Conclusion: This study reveals that physicochemical characteristics in the study area should be monitored periodically because there were isolated high trends in levels of TPH. High levels of TPH were in A2 (Oquwi), U1 (GRA) and I3 (Trans Amadi) which calls for close attention on monitoring. Industrial areas (I1 [Onne], I2 [Agbada] and I3 [Trans-Amadi]) recorded highest levels of TOC. Activities in industrial areas in Port Harcourt have highest impact on levels of TOC in soils as compared to agricultural and urbanized areas. 
Oil and gas activities have negative impact on levels of BTEX. Industrial areas recorded highest levels followed by agricultural areas and lastly urbanized areas. The study concludes that oil and gas activities are a threat to soil health in Industrial and agricultural areas in Port Harcourt.

Acknowledgement: This work was carried out within the PhD Program of World Bank African Centre of Excellence for Oilfield Chemicals Research, in line with the World Bank's mandate for establishing the African Centre of Excellence in University of Port Harcourt in Nigeria. The authors further acknowledge the Regional Universities Forum for Capacity Building in Agriculture (RUFORUM) through Dr. Odogwu A. Blessing and Prof. Ikechukwu O. Agbagwa of University of Port Harcourt for their continual mentorship and financial support under the Carnegie Post-Doctoral funding.

\section{REFERENCES}

Abel, S., Nehls, T., Mekiffer, B., Mathes, M., Thieme, J., \& Wessolek, G. (2014). Pools of sulfur in urban rubble soils. Journal of Soils and Sediments, 15(3), 532-540. https://doi.org/10.1007/s11368014-1014-1

Amponsah, D., Sebiawu, G. E., \& Nagai, H. (2014). Determination Of Amount Of Phosphate And Sulphate In Soil Samples From University Of Cape Coast Farm. INTERNATIONAL JOURNAL OF SCIENTIFIC \& TECHNOLOGY RESEARCH VOLUME, 3(7), 3-7.

Blanchet, G., Gavazov, K., Bragazza, L., \& Sinaj, S. (2016). Responses of soil properties and crop yields to different inorganic and organic amendments in a Swiss conventional farming system. Agriculture, Ecosystems and Environment, 230, 116-126. https://doi.org/10.1016/j.agee.2016.05.032

Cheng, Y., Chen, Y., Jiang, Y., Jiang, L., Sun, L., Li, L., \& Huang, J. (2016). Migration of BTEX and Biodegradation in Shallow Underground Water through Fuel Leak Simulation. BioMed Research International, 2016(Figure 1), 1-9. https://doi.org/10.1155/2016/7040872

Chete, L. N., Adeoti, J. O., Adeyinka, F. M., \& Ogundele, O. (2011). Industrial development and growth in Nigeria: Lessons and challenges, (8), 16. Retrieved from https://www.brookings.edu/wpcontent/uploads/2016/07/L2C_WP8_Chete-et-al1.pdf
Edwards, P. (1998). Sulfur cycling, retention, and mobility in soils: a review. General Technical Report, NE-250, 1-18. Retrieved from http://www.fs.fed.us/ne/newtown_square/publica tions/technical_reports/pdfs/1998/gtrne250.pdf

European Commission. (2013). Soil Contamination : Impacts on Human Health. Science for Environmental Policy, (5), 1-29.

Gboyega, A; Soreinde, T ; Minh le, T \& Shukla, G. . (2011). Political economy of the petroleum sector in Nigeria. Policy Research Working Paper 5730, (July), 48. https://doi.org/http://wwwwds.worldbank.org/external/default/WDSConten tServer/WDSP/IB/2011/08/24/000158349_20110 824134316/Rendered/PDF/WPS5779.pdf

Hassan, M., Hassan, R., Pia, H., Hassan, M., Ratna, S., \& Aktar, M. (2017). Variation of Soil Fertility with Diverse Hill Soils of Chittagong Hill Tracts, Bangladesh. International Journal of Plant \& Soil Science, $\quad 18(1), \quad 1-9$. https://doi.org/10.9734/IJPSS/2017/34975

Hopkins, WG (1999) Introduction to Plant Physiology, 2nd Edition. John Wiley and Sons, New York. Kaiser

Kuang, S., Su, Y., Wang, H., Yu, W., Lang, Q., \& Matangi, R. (2018). Soil Microbial Community Structure and Diversity around the Aging Oil Sludge in Yellow River Delta as Determined by High-Throughput Sequencing, 2018. https://doi.org/10.1155/2018/7861805

Li, S., \& Ma, Y. (2014). Urbanization, Economic Development and Environmental Change. Sustainability, 6(8), 5143-5161. https://doi.org/10.3390/su6085143

Lu, C. A., Zhang, J. F., Jiang, H. M., Yang, J. C., Zhang, J. T., Wang, J. Z., \& Shan, H. X. (2010). Assessment of soil contamination with $\mathrm{Cd}, \mathrm{Pb}$ and $\mathrm{Zn}$ and source identification in the area around the Huludao Zinc Plant. Journal of Hazardous Materials, $\quad$ 182(1-3), 743-748. https://doi.org/10.1016/j.jhazmat.2010.06.097

Ma, R., Martínez-pagán, P., Faz, A., \& Bech, J. (2014). Study of subsoil in former petrol stations in SE of Spain: Physicochemical characterization and hydrocarbon contamination assessment. Journal of Geochemical Exploration, (2013). https://doi.org/10.1016/j.gexplo.2014.10.006 
Mccauley, A., Jones, C., \& Olson-Rutz, K. (2017). Soil $\mathrm{pH}$ and Organic Matter. Nutrient Management, Module No.(4449-8), 16.

MIRA. (2012). Soil quality. PENNSTATE Cooperative Extension College of Agricultural Sciences, 1-8.

Pinedo, J., Ibáñez, R., Lijzen, J. P. A., \& Irabien, Á. (2013). Assessment of soil pollution based on total petroleum hydrocarbons and individual oil substances. Journal of Environmental Management, $\quad 130, \quad 72-79$. https://doi.org/10.1016/j.jenvman.2013.08.048

Prajapati, K., \& Modi, H. A. (2012). the Importance of Potassium in Plant Growth - a Review. Indian Journal of Plant Sciences Jul.-Sept. \& Oct.-Dec, 1(June), 2319-382402.

Smita Tale, K., \& Ingole, S. (2015). A Review on Role of Physico-Chemical Properties in Soil Quality.
Chem Sci Rev Lett, 4(13), 57-66.

Todd Daniel G, Chessin Robert L, C. J. (1999). TOXICOLOGICAL PROFILE FOR TOTAL PETROLEUM HYDROCARBONS ( TPH ). U.S. DEPARTMENT OF HEALTH AND HUMAN SERVICES Public Health Service Agency for Toxic Substances and Disease Registry, (September).

United Nations Interagency Framework Team for Preventive Action. (2012). Renewable Resources and Conflict. Toolkit and Guidance for Preventing and Managing Land and Natural Resources Conflict, UN Interagency Framework Team for Preventative Action, 119. https://doi.org/10.1038/206985b0

World Bank. (2012). What a waste: a global review of solid waste management:Waste Composition. Urban Development Series Knowledge Paper, 1621. https://doi.org/10.1111/febs. 13058 